\title{
REAKTUALISASI DAKWAH WALI SONGO: GERAK DAKWAH KH SAID AQIL SIROJ DALAM MENEBAR ISLAM RAHMATAL LIL ĀLAMIN
}

\author{
Lufaefi \\ Fakultas Ushuludin STFI Sadra Jakarta, Indonesia \\ eepivanosky@gmail.com
}

\begin{abstract}
Dakwah in the modern era, not a bit actualized by the ways of force, even up to spread hatred and rudeness. The hoax issues were made into a spear to 'legalize' the da'wah which he regarded as a very noble teaching. Because the meaning of such da'wah, as a result Islam is often blamed as a religion of terrorism. In the other, there is also a group of people who are afraid of Islam (Islamophobia). This is where the need to reconstruct da'wah models that seem radical. KH. Said Aqil Siroj, a national religious figure who now occupies the chair position of the Chairman of PBNU, has a distinctive model and movement of da'wah as actualized by Wali Songo when spreading Islam. The re-actualization of Wali Songo's teachings is echoed by KH. Said Aqil Siroj through persuasive approach, not force, keep the traditions, persistence of da'wah and reconstruct the meaning of Ahlussunah Wal Jama'ah as social values. Such a form of dakwah proved to have a devastating effect on the growth of Islamic values rahmatal lil 'alamin.
\end{abstract}

Keywords: Wali Songo, KH. Said Aqil Siroj, Peace Da'wah, Islam Rahmatal Lil 'Alamin

\begin{abstract}
Abstrak. Dakwah di era modern sekarang, tidak sedikit diaktualisasikan dengan caracara memaksa, bahkan sampai dengan menebar kebencian dan kekasaran. Isu-isu hoax dijadikan tombak untuk 'melegalkan' dakwah yang dianggapnya sebagai ajaran yang sangat mulia. Karena pemaknaan dakwah yang demikian, akibatnya Islam sering dituding sebagai agama terorisme. Selain itu, muncul juga sekelompok orang yang takut akan Islam (Islamophobia). Di sinilah perlunya merekontruksi model-model dakwah yang terkesan radikal. KH. Said Aqil Siroj, tokoh agama Nasional yang kini menduduki kursi jabatan Ketua Umum PBNU, memiliki model dan gerak dakwah yang khas sebagaimana diaktualisasikan oleh Wali Songo ketika menyebarkan agama Islam. Reaktualisasi ajaran Wali Songo digemakan kembali oleh KH. Said Aqil Siroj melalui pendekatan persuasif, tidak memaksa, menjaga tradisi-budaya, kegigihan berdakwah dan merekonstruksi pemaknaan Ahlussunah Wal Jama'ah sebagai nilai-nilai sosial. Wujud dakwah demikian terbukti memberi efek dahsyat terhadap tumbuhnya nilai-nilai Islam rahmatal lil 'alamin.
\end{abstract}

Kata Kunci: Wali Songo, KH. Said Aqil Siroj, Dakwah Perdamaian, Islam Rahmatal Lil 'Alamin. 


\section{Pendahuluan}

Dakwah merupakan ajaran Islam yang memiliki nilai kemuliaan tinggi di sisi Allah. Wujudnya merupakan harapan besar untuk terus berlangsungnya misi kerasulan Nabi Muhammad saw. Sebaliknya, ketiadaan dakwah merupakan bencana besar yang akan mengikiskan ajaran Islam, dan bahkan, akan mematikan Islam di tengah-tengah kehidupan manusia. ${ }^{1}$ Atas hal demikian agama-khususnya Islam- memerintahkan umat Islam untuk berdakwah demi eksis dan tegaknya ajaran agama mulia tersebut (QS. An-Nahl [16]: 125).

Dalam aktualisasinya, dakwah sekarang tidak semulus sebagaimana dilangsungkan oleh Rasulullah dan para sahabatnya. Kini tersebar garakangarakan yang mengatasnamakan dakwah Islam namun justru mencederahi Islam itu sendiri. Dakwah dilangsungkan dengan cara-cara radikal, sehingga alih-alih berhajat menyedot umat, dakwah Islam malah ditakuti oleh banyak orang. Tidak hanya itu, dakwah juga ditampilkan dengan aksi-aksi kekerasan dan berambisi memberontak aturan yang telah disepakati dalam konstitusi bersama. Endingnya, Islam bukan didekati, tetapi justru dimusuhi. Islam sering dituduh sebagai biang perpecahan dan penyulut isu-isu kekerasan baik di dunia lokal, bahkan internasional. Sebagaimana dikatakan oleh Fawaizul Umam bahwa banyak orang yang mengangap tindakan kekerasan kepada orang lain yang beda keyakinan sebagai refleksi konkrit dakwah dan jihad. ${ }^{2}$

Hal di atas dikuatkan oleh data Komisi Nasional Hak Asasi Manusia (Komnas HAM), yang menyatakan bahwa pada tahun 2010-2013,

1 Didin Hafidhuddin, Dakwah Aktual, (Depok: Gema Insani, 1998), h. 162.

2 Fawaizul Umam, Kala Beragama Tak Lagi Merdeka, (Jakarta: Gramedia, 2013), h. xiii. $\begin{array}{lrr}\text { pengaduan } & \text { tentang } & \text { peristiwa } \\ \text { pelanggaran } & \text { kebebasan } & \text { dan }\end{array}$ keberagaman beragama serta keyakinan atas nama dakwah begitu tinggi. Pada tahun 2010 sendiri Komnas HAM menerima 84 buah pengaduan, yang terdiri dari kasus perusakan, gangguan dan penyegelan rumah ibadah sebanyak 26 kasus, dengan perincian kekerasan terhadap aliran yang diklaim sesat sebanyak 14 kasus, konflik dan sengketa internal 7 kasus, dan 6 kasus pelanggaran terhadap pelarangan Ahmadiyah, serta pelanggaranpelanggaran lainnya. Pada tahun 2011, pengaduan yang masuk sebanyak 83 kasus, dengan 32 kasus terkait pelanggaran atas perusakan tempat ibadah, 21 kasus terkait Ahmadiyah, gangguan dan pelanggaran ibadah sebanyak 13 kasus, dan diskriminasi atas minoritas agama sebanyak 6 kasus. Sedangkan pada tahun 2012, tercatat 68 pengaduan kepada Komnas HAM, dengan perincian sebanyak 20 kasus perusakan dan penyegelan rumah ibadah, konflik dan sengketa internal 19 kasus, gangguan ibadah 17 kasus, dan diskriminasi minoritas 6 kasus. Kemudian pada tahun 2013 Komnas HAM menerima 39 berkas pengaduan, 21 kasus berupa diskriminasi, pengancaman dan kekerasan terhadap pemeluk agama, penghalangan pendirian rumah ibadah sebanyak 9 kasus dan penghalangan terhadap ritual pelaksanaan agama sebanyak 9 berkas. ${ }^{3}$

Data di atas menunjukan betapa telah hilangnya model dakwah yang meskinya diaplikasikan oleh umat beragama. Islam memerintahkan umat manusia untuk berdakwah dengan cara hikmah dan cara-cara kebaikan (mau'zah hasanah). Sebaliknya, Islam tidak sedikitpun memerintah umatnya

3 Abdul Musi Naharong, Teologi Kekerasan: Pandangan Jihad Abdul Salam Faraj dan Imam Samudra, dalam Jurnal Teologi Paramadina, Vol. XVI, No. 1, Tahun. 2010, h. 335 
untuk mengajak kepada kebenaran dengan cara-cara brutal dan merugikan orang lain.

Di sinilah perlunya mencari contoh dakwah yang berefek kesejukan. Dakwah Islam tidak sedikit pun boleh dengan pemaksaan. KH. Said Aqil Siroj merupakan tauladan umat yang memiliki model dakwah sangat khas. Gerak dakwahnya dalam menebar nilainilai Islam terinspirasi dakwah Wali Songo yang memberi kesejukan dalam berdakwah. Melalui pendekatan historisitas dan analisa mendalam terhadap isu-isu kekinian, tulisan ini akan mengupas tuntas model dan gerak dakwah ketua umum PBNU tersebut. Reaktualisasi dakwah Wali Songo yang kembali dibumingkan oleh KH. Said Aqil akan dibahas melalui dua pendekatan tersebut di atas.

\section{Sekilas Tentang KH Said Aqil Siroj}

KH. Said Aqil Siroj merupakan putra kedua dari ulama kampung $\mathrm{KH}$ Aqil Siroj. Kepiawaian ayahnya dalam bidang keilmuan menular kepada anak putranya tersebut. Ia merupakan pengasuh Pondok Pesantren KHAS (Kiai Haji Aqil Siroj) Kempek, Cirebon. Dalam penggembaraan ilmunya, ia banyak mengenyam pendidikan pesantren, seperti di MTM (Majlis Tarbiyatul Mubtadiien) Kempek, Cirebon; Lirboyo, Kediri; Krapyak, Yogyakarta; dan sejumlah pesantren lainnya yang ada di Jawa Timur. Dari sinilah pemikiran Islam ulama Cirebon ini terbentuk. Kepiawaiannya dalam menjaga tradisi ilmu dan budaya di Indonesia, menjadikan dirinya diangkat oleh para ulama untuk mengemban misi Islam yang damai melalui Nahdlatul Ulama

4 Said Aqil Siroj, Islam Kebangsaan: Fiqh Kebangsaan Kaum Santri, (Jakarta: Fatma Press, 1999), h. iv.

${ }^{5}$ Ibid, h.v.

${ }^{6}$ Adi Sucipto Kisswara, Said Aqil Siroj: Islam Menjaga Keutuhan Negara, Nasionalisme
(NU) sejak tahun 2010 sampai sekarang. ${ }^{4}$

Kiai yang sekarang mengasuh pesantren Al-Tsaqofah, Jakarta, tersebut tidak kenyang dengan keilmuan yang didapatinya dari sejumlah pesantren yang telah dikunjunginya. Oleh hal demikian ia melebarkan sayapnya ke Negeri Rasulullah guna menimba ilmu. Tidak tanggung-tanggung, Kiai Said menempa pendidikan di Negeri Nabi Muhammad saw. selama lebih dari 14 tahun melalui Universitas King Abdul Aziz dan Ummul Qurra' Makkah. Endingnya, selama rentan waktu tersebut beliau menyabet gelar doktor dengan disertasinya yang berpangkat cumlaude (mumtaz). ${ }^{5}$

Sepulangnya ke Indonesia, Kiai Said semakin dikenal saat ia diberi amanat memangku jabatan Wakil Katib 'Aam Syuriah PBNU 1994. Saat itu pula, berbagai gerakan dakwahnya membuatnya dikenal di mana-mana. Berbagai seminar, simposium, lokakarya dan diskusi ia galakkan demi dakwah Islam dan demi Islam yang damai. Hingga akhirnya, karena kecintaan kepada Islam dan Negara yang santun, dalam dakwahnya selalu memgajak dalam persatuan, perdamaian, dan mensinergikan antara Islam dan Nasioanlisme. ${ }^{6}$ Hal itupun kemudian banyak dicontoh oleh berbagai ulama di dunia untuk menciptakan perdamaian dan persatan melalui sinergitas Islam dan kecintaan terhadap negara.

Pada tahun 2010 hingga sekarang, KH. Said Aqil Siroj dipercaya memangku kursi jabatan ketua umum PBNU (Pengurus Besar Nahdlatul Ulama). Organisasi masyarakat Islam terbesar di Indonesia - bahkan di dunia - tersebut,

\footnotetext{
Bagian dari Iman, dalam http://kompas.id/baca/x/politik/2017/05/25/ said-aqil-siroj-islam-menjaga-keutuhan-negaranasionalisme-bagian-dari-iman/, diakses pada 13 Maret 2017, pkl. 11.24 WIB.
} 
membawanya semakin cinta kepada Islam dan keindonesiaan. Gaung dakwah persatuan dan perdamaian yang terus digelorakan dalam setiap orasinya, menjadi ciri khas pergerakan KH. Said Aqil. Sehingga berbagai penghargaan nasional dan internasional atas nama cendikiawan muslim perdamaian tak setitik disabet oleh beliau. Hal itu dibuktikan pada tahun 2011, Penerbit Republika memberinya penghargaan atas nama Cendikiawan Muslim Perdamaian, pada tahun 2009 dunia Internasional juga mendaulat dirinya sebagai tokoh pemersatu umat, dan terakhir tahun 2017 juga tercatat sebagai tokoh perubahan dunia perdamaian. ${ }^{7}$ Misi Islam dan damai tak hentinya dibumingkan di bumi pertiwi oleh KH. Said Aqil Siroj, demi Islam dan Dunia yang rukun, akur, dan tentram dengan nilai-nilai Islam Rahmatal Lil 'Alamin.

\section{Potret Strategi Dakwah di Indonesia}

Dakwah adalah sebuah alat komunikasi, baik verbal, tulisan atau kondisional guna menarik umat dalam memeluk ajaran agama. Dakwah menjadi barometer akan lanjut atau tidaknya misi keislaman yang dibawa oleh Rasulullah saw. Di sinilah perlunya dakwah yang menarik dan kreatif. Dakwah harus dengan cara-cara yang dapat disukai oleh objek dakwah (mad'u) agar misi Islam mudah untuk tersampaikan dan terwujudkan. Dan lagi, dakwah tidak sepatutnya dilakukan dengan cara-cara kekerasan,

\footnotetext{
7 Anton Hatri, Said Aqil Tokoh Muslim Berpengaruh di Dunia, dalam mediaindonesia.com/news/read/71405/SaidAqil-Tokoh-Muslim-Berpengaruh-diDunia/2016/10/11. Diakses pada 14 Maret 2018, pkl. 5.42 WIB.

8 Mukhlisuddin Ilyas, Aceh dan Romantisme Politik, (Yogyakarta: Dianda Primamitra Media, 2008), h. 138.

9 Djohan Efendi, Merayakan Kebebasan Beragama: Bunga Rampai Merayakan 70 Tahun
}

pemaksaan, perusakan, atau merugikan orang lain. ${ }^{8}$

Indonesia merupakan negara berpenduduk muslim terbesar di dunia. Dengan multikultural yang ada di dalamnya, kontestasi dakwah pun menjadi ajang yang beragam antar satu kelompok dengan kelompok lainnya dalam menyedot masa.

Potret strategi dakwah di Indonesia, sebagaimana menurut Djohan Efendi, sama dengan potret penyebaran agama Islam dan media yang digunakan oleh para pedagang dan mubaligh dalam menyebarkan agama Islam di Indonesia. ${ }^{9}$ Masih menurutnya, strategi yang digunakan oleh para penyebar dakwah Islam di Indonesia yaitu melalui perdagangan, perkawinan, pendidikan, kesenian, tasawuf dan politik. ${ }^{10}$ Berikut penjelasannya:

\section{Perdagangan}

Pada tahap awal, saluran dakwah yang dipergunakan untuk menyebarkan Islam adalah perdagangan. Hal itu dapat dibuktikan dengan ramainya lalu lintas perdagagan pada kurun waktu abad ke7 hingga ke-16 di negeri bagian Barat, Tenggara dan Timur benua Asia. Media dakwah melalui dagang ini sangat menguntungkan, karena para raja pada saat itu juga ikut serta dalam aktivitas berdagang, bahkan mereka menjadi pemilik kapal dan saham perdagangan tersebut.

Data ini juga diperkuat oleh Tome' Pires yang mengatakan bahwa para pedagang yang berasal dari luar

Djohan Efendi, (Jakarta: ICPR \& Kompas, 2011), h. 486.

10 Djohan Efendi, Merayakan Kebebasan Beragama: Bunga Rampai Merayakan 70 Tahun Djohan Efendi, h. 489-494. Penjabaran terkait metode dakwah dari mulai perdagangan sampai dengan politik semuanya merupakan penjabaran dari: Lihat: Jajat Burhanuddin, Ulama dan Kekuasaan: Pergumulan Elite Politik Muslim dalam Sejarah Indonesia. (Jakarta: Noura Book, 2012), h. 17-21. 
negeri banyak yang bermukim di pulau Jawa. Mereka beragama Islam, sedangkan di pulau Jawa tersebut, pada saat itu, masih belum mengenal Islam. Para pedagang tersebut membangun masjid, mendatangkan para tokoh agama dari negaranya dan melakukan islamisasi sedikit demi sedikit melalui perkembangan perdagangan yang berlangsung.

Hubungan perdagangan ini benar-benar dimanfaatkan para pedagang muslim untuk menyebarkan agama Islam kepada siapapun dan di manapun. Keberhasilan penyebaran Islam melalui perdagangan ini juga disebabkan karena jalur perdagangan inernasional sebagian besarnya dikuasai oleh pedagang muslim. Maka apabila para penguasa lokal Indonesia ingin terlibat dalam perdagangan tingkat internasional, maka mereka harus terlibat aktif dengan para pedagang muslim.

\section{Perkawinan}

Dari aspek ekonomi, para pedagang muslim memiliki status sosial ekonomi yang lebih baik daripada kebanyakan penduduk pribumi. Hal ini menyebabkan banyak penduduk pribumi, terutama para wanita, yang tertarik untuk menjadi istri-istri para saudagar muslim. Hanya saja ada ketentuan hukum Islam, bahwa para wanita yang akan dinikahi harus diislamkan terlebih dahulu. Para wanita dan keluarga mereka tidak merasa keberatan, karena proses pengislaman hanya dengan mengucapkan dua kalimat syahadat, tanpa upacara atau ritual rumit lainnya.

Setelah itu, mereka menjadi komunitas muslim di lingkungannya sendiri. Keislaman mereka menempatkan diri dan keluarganya berada dalam status sosial dan ekonomi cukup tinggi. Sebab, mereka menjadi muslim Indonesia yang kaya dan berstatus sosial terhormat. Kemudian setelah mereka memiliki keturunan, lingkungan mereka semakin luas. Akhirnya timbul kampung-kampung dan pusat-pusat kekuasaan Islam.

Dalam

perkembangan

berikutnya, ada pula para wanita muslim yang dikawini oleh keturunan bangsawan lokal. Hanya saja, anak-anak para bangsawan tersebut harus diislamkan terlebih dahulu. Dengan demikian, mereka menjadi keluarga muslim dengan status sosial ekonomi dan posisi politik penting di masyarakat.

Jalur perkawinan ini lebih menguntungkan lagi apabila terjadi antara saudagar muslim dengan anak bangsawan atau anak raja atau anak adipati. Karena raja, adipati, atau bangsawan itu memiliki posisi penting di dalam masyarakatnya, sehingga mempercepat proses Islamisasi. Beberapa contoh yang dapat dikemukakan di sini adalah, perkawinan antara Raden Rahmat atau Sunan Ngampel dengan Nyai Manila, antara Sunan Gunung Jati dengan Puteri Kawunganten, Brawijaya dengan Puteri Campa, orangtua Raden Patah, raja kerajaan Islam Demak dan lain-lain.

\section{Pendidikan}

Proses Islamisasi di Indonesia juga dilakukan melalui media pendidikan. Para ulama banyak yang mendirikan lembaga pendidikan Islam, berupa pesantren. Pada lembaga inilah, para ulama memberikan pengajaran ilmu keislaman melalui berbagai pendekatan sampai kemudian para santri mampu menyerap pengetahuan keagamaan dengan baik. Setelah mereka dianggap mampu, mereka kembali ke kampung halaman untuk mengembangkan agama Islam dan membuka lembaga yang sama. Dengan demikian, semakin hari lembaga pendidikan pesantren mengalami 
perkembangan, baik dari segi jumlah maupun mutunya.

Lembaga pendidikan Islam ini tidak membedakan status sosial dan kelas, siapa saja yang berkeinginan mempelajari atau memperdalam pengetahuan Islam, diperbolehkan memasuki lembaga pendidikan ini. Dengan demikian, pesantren-pesantren dan para ulamanya telah memainkan peran yang cukup penting di dalam proses pencerdasan kehidupan masyarakat, sehingga banyak masyarakat yang kemudian tertarik memeluk Islam.

Di antara lembaga pendidikan pesantren yang tumbuh pada masa awal Islam di Jawa, adalah pesantren yang didirikan oleh Raden Rahmat di Ampel Denta. Kemudian pesantren Giri yang didirikan oleh Sunan Giri, popularitasnya melampaui batas pulau Jawa hingga ke Maluku. Masyarakat yang mendiami pulau Maluku, terutama Hitu, banyak yang berdatangan ke pesantren Sunan Giri untuk belajar ilmu agama Islam. Bahkan Sunan Giri dan para ulama lainnya pernah diundang ke Maluku untuk memberikan pelajaran agama Islam. Banyak di antara mereka yang menjadi hatib, muazin, hakim (qadli) dalam masyarakat Maluku dengan memperoleh imbalan cengkeh.

Dengan cara-cara seperti itu, maka agama Islam terus tersebar ke seluruh penjuru Nusantara, hingga akhirnya banyak penduduk Indonesia yang menjadi muslim. Oleh karena itu, dapat dikatakan bahwa model pendidikan pesantren yang tidak mengenal kelas menjadi media penting di dalam proses penyebaran Islam di Indonesia, bahkan kemudian diadopsi untuk pengembangan pendidikan keagamaan pada lembaga-lembaga pendidikan sejenis di Indonesia.

\section{Tasawuf}

Jalur lain yang juga tidak kalah pentingnya dalam proses Islamisasi di Indonesia adalah tasawuf. Salah satu sifat khas dari ajaran ini adalah akomodasi terhadap budaya lokal, sehingga menyebabkan banyak masyarakat Indonesia yang tertarik menerima ajaran tersebut. Pada umumnya, para pengajar tasawuf atau para sufi adalah guru-guru pengembara, dengan sukarela mereka menghayati kemiskinan, juga seringkali berhubungan dengan perdagangan, mereka mengajarkan teosofi yang telah bercampur dengan ajaran yang sudah dikenal luas masyarakat Indonesia. Mereka mahir dalam hal magis, dan memiliki kekuatan menyembuhkan. Di antara mereka ada juga yang menikahi gadis-gadis para bangsawan setempat.

Dengan tasawuf, bentuk Islam yang diajarkan kepada para penduduk pribumi mempunyai persamaan dengan alam pikiran mereka yang sebelumnya memeluk agama Hindu, sehingga ajaran Islam dengan mudah diterima mereka. Di antara para sufi yang memberikan ajaran yang mengandung persamaan dengan alam pikiran Indonesia praIslam adalah Hamzah Fansuri di Aceh, Syeikh Lemah Abang, dan Sunan Panggung di Jawa. Ajaran mistik seperti ini terus dianut bahkan hingga kini.

\section{Kesenian}

Saluran Islamisasi melalui kesenian yang paling terkenal adalah melalui pertunjukkan wayang. Seperti diketahui bahwa Sunan Kalijaga adalah tokoh yang paling mahir dalam mementaskan wayang. Dia tidak pernah meminta upah materi dalam setiap pertunjukan yang dilakukannya. Sunan Kalijaga hanya meminta kepada para penonton untuk mengikutinya mengucapkan dua kalimat syahadat. Sebagian besar cerita wayang masih diambil dari cerita Ramayana dan 
Mahabarata, tetapi muatannya berisi ajaran Islam dan nama-nama pahlawan muslim.

Selain wayang, media yang dipergunakan dalam penyebaran Islam di Indonesia adalah seni bangunan, seni pahat atau seni ukir, seni tari, seni musik dan seni sastra. Di antara bukti yang dihasilkan dari pengembangan Islam awal adalah seni bangunan Masjid Agung Demak, Sendang Duwur, Agung Kasepuhan, Cirebon, Masjid Agung Banten, dan sebagainya. Seni bangunan masjid yang ada, merupakan bentuk akulturasi dari kebudayaan lokal Indonesia yang sudah ada sebelum Islam, seperti bangunan candi. Salah satu dari sekian banyak contoh yang dapat kita saksikan hingga kini adalah Masjid Kudus dengan menaranya yang sangat terkenal itu. Hal ini menunjukkan sekali lagi bahwa proses penyebaran Islam di Indonesia yang dilakukan oleh para penyebar Islam melalui cara-cara damai dengan mengakomodasi kebudayaan setempat. Cara ini sangat efektif untuk menarik perhatian masyarakat pribumi dalam memahami gerakan Islamisasi yang dilakukan oleh para mubalig, sehingga lambat laun mereka memeluk Islam.

\section{Politik}

Di Maluku dan Sulawesi Selatan, kebanyakan rakyat masuk Islam setelah rajanya masuk Islam terlebih dahulu. Pengaruh politik raja sangat membantu tersebarnya Islam di wilayah ini. Jalur politik juga ditempuh ketika kerajaan Islam menaklukkan kerajaan non Islam, baik di Sumatera, Jawa, maupun Indonesia bagian Timur.

\section{Sekilas Tentang Wali Songo}

Kata wali songo berasal dari kata wali dan songo. Kata wali berasal dari bahasa Arab dan merupakan singkatan dari waliyullah yang diartikan"orang yang mencintai dan dicintai Allah", sedangkan kata songo berasal dari bahasa Jawa yang diartikan sembilan. Wali songo adalah sembilan orang yang mencintai dan dicintai Allah.

\section{Syekh Maulana Malik Ibrahim}

Syekh Maulana Ibrahim juga dipanggil dengan sebutan Syeikh Maghribi, beliau mempunyai 2 orang putra yang yang bernama Raden Rahmat (Sunan Ampel) dan Sayid Ali Murtadha atau Raden Santri. Maulana Malik Ibrahim datang ke Jawa pada tahun 1404M. Dan beliau wafat pada tahun $1410 \mathrm{M}$, dan dimakamkan di Gresik. Karena beliau adalah seorang wali yang menyebarkan agama Islam yang gigih tanggung dan berani maka terdapat tulisan Arab pada batu nisannya. Dan Allah juga memberikan kepada beliau rahmat dan keridhaannya serta dimasukkan dalam surga-Nya.

\section{Sunan Ampel}

Raden Rahmat adalah nama asli dari Sunan Ampel. Beliau tinggal di Ampel sehingga beliau dipanggil dengan sebutan Sunan Ampel. Beliau mendirikan pesantren di Ampel Denta dengan kesibukannya dan berbagai aktivitas di pesantrennya, dan beliau tidak setuju dengan adanya adat-istiadat orang Jawa seperti kebiasaan sesaji dan selamatan.

\section{Sunan Giri}

Raden paku adalah nama asli dari Sunan Giri dan beliau dijuluki dengan sebutan Muhammad 'Ainul Yaqin. Beliau putra dari Maulana Ishak dan putri dari Dewi Sekardadu. Raden Paku dikenal dengan sebutan Sunan Giri karena beliau mendirikan pesantren di dekat gunung yang bernama gunung Giri.

\section{Sunan Bonang}

Sunan Bonang atau dipanggil Raden Makdum Ibrahim dan beliau adalah putra Sunan Ampel. Sunan 
Bonang sangat besar peranannya dalam mendirikan kerajaan Islam Demak.

\section{Sunan Kalijaga}

Raden Said atau Jaka Said adalah nama panggilan beliau diwaktu kecilnya. Beliau adalah putra pengusaha di Tuban, dan ayahnya bernama Raden Sahur Temenggung Wilatika (Bupati Tuban). Nama Kalijaga berasal dari bahasa Arab, yaitu Qadi Zaka yang berarti pemimpin atau pelaksana dalam menegakkan kesucian.

\section{Sunan Kudus}

Ja'far Siddiq adalah nama kecil dari Sunan Kudus. Beliau tinggal di Kudus, yang merupakan putra Sunan Ngudung atau Undung, dan beliau dipercaya oleh masyarakat Kudus dalam memimpin agama sekaligus memimpin pemerintahan di daerah tersebut. Beliau dijuluki gelar al-'Alim (orang yang luas ilmunya).

\section{Sunan Drajat}

Masih munat adalah nama asli dari Suanan Drajat. Beliau adalah putra kedua dari Sunan Ampel. Beliau hijrah ke Desa Drajat di Lamongan setelah belajar agama dari ayahnya dan mendirikan pesantren di Lamongan. Beliau sangat santun dan menyayangi fakir miskin dan anak yatim.

\section{Sunan Muria}

Umar Said nama panggilan atau sebutan dari Sunan Muria. Sedangkan nama aslinya adalah Raden Said atau Raden Prawoto. Beliau putra dari Sunan Kalijaga dan kesenianlah salah satunya dakwah yang beliau gunakan.

\section{Sunan Gunung Jati}

Sunan Gunung Jati juga termasuk golongan/keturunan darah yang terhormat baik dari keturunan ibunya maupun keturunan bapaknya. Ibunya seorang putri Raja Pajajaran dan bapaknya masih ada keturunan darah dari Nabi Muhammad serta mempunyai keturunan dengan para sembilan wali. ${ }^{11}$

\section{Moralitas Dakwah Wali Songo}

\section{Syekh Maulana Malik Ibrahim}

Ajaran yang beliau gunakan dalam menyebarkan ajaran Islam adalah dengan melayani kebutuhan masyarakatnya setiap harinya dan menunjukkan atau mengamalkan ilmu yang dimiliki oleh Maulana Malik Ibrahim. Dalam menyebarkan ajaran agama Islam beliau tidak langsung mengajarkannya apa itu Islam, akan tetapi melalui jalur pemenuhan kebutuhan dasar manusia. Dan berdakwah dengan cara yang dapat diterima oleh akal pikiran manusia, sehingga agama Islam dapat diterima oleh manusia dengan mudah. ${ }^{12}$

\section{Sunan Ampel}

Ajaran yang dibawa oleh Sunan Ampel dalam menyebarkan agama Islam adalah dengan menggunakan cara membuat kipas anyaman yang terbuat dari rotan, dan kipas tersebut bukan hanya sekedar kipas biasa akan tetapi bisa menyembuhkan orang sakit dan kipas tersebut dibagikan kepada masyarakat atau penduduk sekitarnya, dan penduduk tersebut hanya membalasnya dengan kalimat syahadat banyak sekali penduduk yang senang dan meminta untuk menyembuhkan penyakitnya kepada

12 Abu Hamid, Syaikh Yusuf Makasar: Seorang Ulama, Sufi dan Pejuang, Jakarta: Yayasan Obor Indonesia, 1994, h. 171. 
beliau. Itulah cara Sunan Ampel dalam menyebarkan ajaran agama islam. ${ }^{13}$

Esensi dari penjelasan di atas bahwa dakwah yang dilakukan oleh Sunan Ampel ialah menggunakan perantara apa yang dibutuhkan manusia saat itu, untuk kemudian ia gagaskan ajarannya dalam interaksi saat memberi apa kebutuhan mereka yang belum mengenal Islam.

\section{Sunan Giri}

Ajaran yang dibawa oleh Sunan Giri dalam menyebarkan agama Islam ialah dengan menggunakan cara membuat wayang kulit, yang waktunya pada saat peresmian Masjid Demak. Dengan wayang kulitlah sebagai media dakwah yang digunakan oleh Sunan Giri. Akan tetapi, beliau mengubahnya wayang kulit tersebut dengan wayang kulit biasa yang awalnya seperti manusia. Karena menurutnya dalam Islam tidak diperbolehkan membuat sesuatu yang mati yang menyerupai manusia. ${ }^{14}$

\section{Sunan Bonang}

Ajaran yang dibawa oleh Sunan Bonang dalam menyiarkan agama Islam dengan menggunakan cara menciptakan alat musik Jawa yang biasa disebut gending-gending. Dan para wali lainnya membuat gending-gending Jawa untuk berdakwah dan diciptakanlah gendinggending Jawa itu penuh dengan ajaranajaran agama Islam dan gending-gending tersebut banyak disukai atau disenangi oleh masyarakat.

Dan ketika rakyat berkumpul dengan Sunan Bonang untuk belajar tembang, tanpa sengaja mereka yang belajar tembang sudah diajarkan ajaran Islam dan mereka telah diberi pelajaran agama Islam yang terdapat di dalam tembang tersebut. Dan beliau berdakwah

13 Sri Mulyati, Tasawuf Nusantara: Rangkaian Mutiara Sufi Terkemuka, (Jakarta: Penerbit Kencana, 2017), h. 60.

14 Abu Hamid, Syaikh Yusuf Makassar: Seorang Ulama, Sufi dan Pejuang, h. 62. secara berkeliling dari daerah yang satu ke daerah yang lainnya. ${ }^{15}$

\section{Sunan Kalijaga}

Ajaran yang dibawa oleh sunan kalijaga dalam menyebarkan agama Islam dengan menggunakan cara kesenian sebagai sarana dakwah seperti seni wayang yang dahulu penuh dengan ajaran Hindu dan Buddha akan tetapi sekarang menjadi seni wayang yang penuh dengan ajaran agama Islam yang diajarkan oleh Sunan Kalijaga begitu pula dengan hiburan-hiburan yang bersifat Islami, dan beliau merupakan wali yang paling kreatif dalam keseniannya. ${ }^{16}$

\section{Sunan Kudus}

Ajaran yang dibawa oleh Sunan Kudus dalam menyebarkan agama Islam dengan menggunakan cara menyampaikan secara lisan atau dakwah bil lisan. Suatu ketika beliau membeli sapi dan diletakkan di depan rumahnya sedangkan masyarakat sekitarnya rata-rata beragama HinduBuddha, sepengetahuan mereka sapi adalah hewan suci yang tidak boleh disembelih dan barang siapa yang menyembelihnya akan mendapatkan dosa.

Suatu hari penduduk sekitarnya berkumpul didepan rumah beliau dan beliau menjelaskan tentang sapi tersebut karena pada waktu kecilnya kehausan dan disusui oleh sapi tersebut dan penduduk kagum atas penyampaian Sunan Kudus, dan beliau adalah Dewa Wisnu. Dan beliau mencerikatan tentang Surat al-Baqarah yang artinya sapi di dalam Alquran dan penduduk tersebut semakin penasaran akan ajaran Islam dan mereka setiap hari

15 Ahmad Chodim, Sunan Kalijaga, (Jakarta: Serambi, 2013), h. 156.

16 Ahmad Chodim, Sunan Kalijaga, h. 156. 
selalu mendatangi rumah beliau untuk belajar agama Islam. ${ }^{17}$

\section{Sunan Drajat}

Ajaran yang dibawa oleh Sunan Drajat dalam menyebarkan agama Islam dengan menggunakan cara yang bersumber dari Alquran, sunnah, ijma', qiyas seperti Sunan Ampel ayahnya. Dengan ilmu yang sangat luas sehingga Sunan Drajat gampang dalam menyebarkan ajaran agama Islam terhadap masyarakat setempat. ${ }^{18}$

\section{Sunan Muria}

Ajaran yang dibawa oleh Sunan Muria dalam menyebarkan agama Islam dengan menggunakan kesenian seperti wayang kulit dan gemelan-gemelan sebagai sarana dakwahnya, dan beliau satu-satunya wali yang mempertahankan kesenian dalam dakwahnya. Beliau sangat mengutamakan dakwahnya terhadap masyarakat pedagang, nelayan, pedesaan dan rakyat jelata dengan cara yang sangat halus. ${ }^{19}$

\section{Sunan Gunung Jati}

Ajaran yang dibawa oleh Sunan Gunung Jati dalam menyebarkan agama Islam dengan menggunakan cara tidak bekerja dengan sendirinya beliau selalu mengikuti musyawarah dengan wali yang lainnya dan membantu dalam pembangunan Masjid Demak. Sunan Gunung Jati selalu mencoba untuk mendekati masyarakat agar lebih mudah dalam menyampaikan ajaran agama Islam, serta menghubungkan antara daerah yang satu ke daerah yang lainnya dalam menjalankan dakwahnya. ${ }^{20}$

17 Musthofa Bisri, Koridor: Renungan A. Musthofa Bisri, (Jakarta: Kompas, 2010), h. 47.

18 Muhammad Nurul Ibad, Perjalanan dan Ajaran Gus Meik, (Yogyakarta: Lkis. 2007), h. 231.

19 Daniel Agus Maryanto, Masjid Agung Demak, (Jakarta: Grasindo, 2003), h. 1.
Sembilan wali di atas memiliki model dakwah yang hampir sama. Esensi paling penting terhadap moralitas dakwah yang diajarkan wali songo adalah gerak dakwahnya yang santun, sejuk, ramah, dan mampu mendialogkan antara Islam dan budaya lokal. Sebagaimana menurut Muhammad Nur, pengembangan Islam yang diajarkan Wali Songo dengan warna tradisi sangat manjur. Dengan tanpa merubah ajaran Islam di dalamnya, para wali menerjemahkan Islam dalam budaya lokal. Selain itu, gerak mereka yang persuasif kepada masyarakat tingkat bawah membuat Islam mudah dipahami oleh masyarakat tingkat bawah. ${ }^{21}$ Dakwah yang diajarkan oleh Wali Songo merupakan dakwah yang damai dan santun, yang akan mudah untuk diterima oleh banyak orang. Dakwah yang tidak didasari dengan jalan kekerasan tersebut akan mewujudkan Islam damai di tengahtengah masyarakat.

Dakwah demikian tentu saja benar dianjurkan di dalam Alquran QS. An-Nahl: 125:

Serulah (manusia) kepada jalan Tuhan-mu dengan hikmah dan pelajaran yang baik dan bantahlah mereka dengan cara yang baik. Sesungguhnya Tuhanmu Dialah yang lebih mengetahui tentang siapa yang tersesat dari jalan-Nya dan Dialah yang lebih mengetahui orangorang yang mendapat petunjuk.

\section{Islam Damai dan Masa Kini}

Sebagai ajaran yang agung, Islam harus menjadi payung bagi seluruh umat manusia, sekalipun non-muslim. Islam harus mewujudkan citra kedamaian terhadap seluruh alam. Kedamaian Islam tercermin dari peristiwa piagam

\footnotetext{
${ }^{20}$ Uka Tjandrasasmita, Arkeologi Islam Nusantara, (Jakarta: Gramedia, 2009), h. 123.

21 Muhammad Nur, Menyemai Kreator Peradaban, (Jakarta: Penerbit Zaman, 2013), h. 206.
} 
Madinah yang dipimpin oleh Rasulullah saw. Pranata sosial yang dibangun oleh Nabi sungguhpun mayoritas Muslim. Tetapi justru menggunakan payung "Piagam Madinah". Dalam pasal yang memuat 47 pasal tersebut, tidak sesekalipun disebutkan Islam atau Alquran, tidak lain misinya adalah menyatukan dan mendamaikan umat manusia yang terdiri atas berbagai etnis, yaitu etnis Muhajirin, etnis Madinah meliputi ras Khazraj, Qainuqa, Nadlir dan Quraidlah yang dengan background Yahudi, Nasrani, Islam dan Musyrik. ${ }^{22}$

Multikulturalisme

bangsa

Indonesia agaknya sangat cocok untuk disandingkan dengan parameter Piagam Madinah. Berbagai macam agama, suku, ras, budaya, etnis, kepercayaan, Islam Indonesia harus mampu menjadi garda depan perdamaian. Egoisme kesukuan atau keagamaan harus sesegera mungkin disingkirkan guna mewujudkan masyarakat yang kasih sayang, damai dan adil. Misi Islam rahmatal lil 'alamin harus terus dikampanyekan demi keutuhan dalam keberagaman bangsa Indonesia. Islam dan kedamaian harus disandingkan dalam usaha memajukan peradaban dan keagamaan umat Indonesia.

Misi perdamaian agaknya tidak akan tercapai kecuali dengan jalan yang santun dalam menebar nilai-nilai keagamaan, apapun agamanya. Allah Swt. berfirman di dalam surat AlBaqarah [2]: 62:

"Sesungguhnya orang-orang mukmin, orang-orang Yahudi, orang-orang Nasrani dan orangorang Shabiin, siapa saja diantara mereka yang benar-benar beriman kepada Allah, hari kemudian dan beramal saleh, mereka akan

22 Zuhairi Misrawi, Madinah: Kota Suci, Piagam Madinah dan Teladan Muhammad Saw., (Jakarta: Kompas, 2009), h. 7.

${ }^{23}$ Said Aqil Siroj, Islam Kebangsaan: Fiqh Politik Kaum Santri, h. 246. menerima pahala dari Tuhan mereka, tidak ada kekhawatiran kepada mereka, dan tidak (pula) mereka bersedih hati."

Secara tekstualitas, ayat tersebut memberi indikasi akan beragamnya agama manusia. Selain itu, ayat tersebut menggoreskan pemahaman yang akan meredam kontraversi agama-agama di Indonesia, bahkan di dunia. Jika kita renungkan secara mendalam, ayat tersebut tidak hanya meretaskan benteng-benteng syariat yang kebanyakan bersifat dzanniyat, tapi juga memupus pagar-paga absolutisme agama yang banyak terefleksi pada doktrin-doktrin teologi.

Bahkan menurut Said Aqil, Allah Swt. dalam nash tadi, kebajikan dan balasan baik tidak akan dilihat dari subjek dengan predikat Mukmin, Yahudi, Kristiani, Majuzi, Budhis, atau label-label agama lainnya. ${ }^{23}$ Dari sinilah dakwah Wali Songo menjadi cocok dan benar. Ajakan yang dilakukan oleh para waliyullah dalam mengajak menuju kebenaran, sungguh pun tidak melalui pemaksaan. Bahkan, mereka tidak sedikitpun merusak paksa ajaran, budaya, atau ritual-ritual agama-agama Hindu yang sudah lama tertanam dalam kepercayaan masyarakat. ${ }^{24}$ Keberhasilan dakwah Wali Songo tergambarkan manakala ia berhasil mengislamkan 80\% masyarakat Jawa untuk memeluk Islam, yang sebelumnya terpagar dalam ritual dan ajaran agama-agama nonIslam. ${ }^{25}$

\section{KH. Said Aqil Siroj dan Dakwah Wali Songo}

Keberhasilan dakwah Wali Songo sudah seharusnya menjadi cermin masyarakat Muslim dalam mengemban

${ }^{24}$ Purwadi, Jejak Para Wali dan Ziarah Spiritual, (Jakarta: Kompas, 2006), h. 16.

25 Doni Febriando, Kembali Menjadi Manusia, (Jakarta: Elexmedia Komputindo, 2014), h. 22. 
dakwah di dunia. Para agamawan dan penyeruh dakwah harus meneladani gerak dakwah yang telah diaktualisasikan oleh Wali Songo.

Salah satu ulama Indonesia yang telah berhasil mengaktualisasikan ajaran Islam dan meneladani dakwah Wali Songo ialah KH. Said Aqil Siroj. Barometer tersebut dapat kita buktikan dengan pergerakan yang dilakukan oleh Ketua PBNU tersebut dalam menebar nilai-nilai keramahan dan perdamaian di dalam agama Islam kepada masyarakat Indonesia, bahkan dunia. Gerakangerakan dakwah tersebut tercermin dengan beberapa sikap yang mirip dengan aktualisasi dakwah yang telah dilaksanakan oleh para Wali, sebagai berikut:

Pertama, persuasif. KH. Said Aqil siroj merupakan sosok yang arif dan mau bergaul dengan siapapun, serta tidak memiliki rasa besar kepala kepada siapa saja walaupun dirinya seorang tokoh besar organisasi masyarakat terbesar Nahdlatul Ulama. Cara beliau mendakwahkan Islam tidak dengan marah, namun dengan cara yang murah dan pemaaf. Salah satu sikapnya itu adalah ketika dirinya dicemooh oleh pidato Bupati Lampung pada peringatan Hari Santri Nasional 2017. Dilansir oleh Tribun Lampung bahwa, Said Aqil sama sekali tidak marah apalagi mendendam. Ia langsung memberi maaf kepada bupati tersebut dan bahkan ia menerima kunjungan Bupati Lampung tersebut saat berkunjung ke kantor PBNU Jakarta. ${ }^{26}$ Sikap persuasif inilah yang pada gilirannya membuat banyak orang terkagum-kagum. Walau dirinya telah

26 Kristian Erdianto, Ini Tanggapan PBNU Terkait Pidato Bupati Lampung yang Dinilai Lecehkan Said Aqil Siroj, dalam lampung.tribun.com/2017/10/24/initanggapan-pbnu-terkait-pidato-bupatilampung-yang-dinilai-lecehkan-said-aqil-siroj, diakses pada 13 Maret 2018, pkl. 13.07 WIB.

27 Ceramah Said Aqil Siroj dalam acara Newsmaker Metro TV, dengan judul "Pada Islam banyak difitnah, namun pribadinya tetap sabar dan tegar.

Kedua, mempertahankan tradisi dan budaya. Menurut KH. Said Aqil, kenyataan Indonesia sebagai negara yang memiliki sosio-antropologi merupakan hal yang tidak bisa dibantahkan. Akan tetapi, fakta yang muncul kemudian tumbuhnya ismeisme yang sering menyulut anarkisme. Di situlah kemudian agama menjadi goyah. Peran agama tidak bisa terwujudkan jika tanpa menggandengan tradisi dan budaya. Agama dan tradisibudaya harus berjalan beriringan guna menciptakan bangsa yang berkeadaban. ${ }^{27}$

Selain hal di atas, ruang-ruang kebudayaan dan tradisi masyarakat juga harus memberi wahana yang seluasluasnya bagi internalisasi agama dan spiritnya, guna kokohnya akar tradisi dan budaya yang ada. Sehingga dengan itu, kekuatan politik dan negara tidak akan melakukan tindakan hegemonik terhadap praktik keagamaan. ${ }^{28}$ Spirit agama harus menjadi ruh kebangsaan kita. Sedangkan kebangsaan hanya akan kokoh dengan peran budaya dan tradisi yang ada. Oleh hal itu, agama tanpa tradisi budaya seperti tanpa nama.

Ketiga, kegigihan berdakwah. KH. Said Aqil Siroj merupakan ulama yang setiap harinya diwarnai dengan kegiatan dakwah. Cita-cita disemayamkannya nilai Islam rahmatal lil 'alamin kepada masyarakat, khususnya Indonesia, adalah keinginan agung yang selalu dikampanyekannya, meskipun tidak sedikit tantangan-tantangan yang

Nusantara Budaya Sebagai Infrastruktur Agama", didownload pada 13 Maret 2018, pkl. 13.13 WIB.

${ }^{28}$ Ceramah Said Aqil Siroj dalam acara Haul dan Tasyakkur Ponpes Khas Kempek, pada 13 Juni 2017 di Pondok Pesantren kempek Cirebon. 
menghadang dan mencoba melukainya. ${ }^{29}$

Bagi Said Aqil, cemoohan dan hinaan dalam berdakwah merupakan bumbu dalam berdakwah. Jika pun teladan Nabi Muhammad saja dikucilkan dalam berdakwah, sudah tidak aneh jika umatnya pun mengalami hal yang setimpal, apalagi jika sekedar bully-an.

Keempat, reinterpretasi ajaran Ahlussunah wal Jamaah. Ahlussunah wal jamaah merupakan keyakinan salah satu kelompok yang berpegang teguh bahwa Nabi Muhammad saw. dan seluruh sahabat Nabi adalah panutan sepanjang masa. Dalam ajaran tersebut diyakini bahwa 20 sifat wajib bagi Allah. 20 sifat mustahil, 1 sifat jaiz Allah, 4 wajib bagi Rasul, 4 sifat mustahil, dan 1 sifat jaiz merupakan hal yang harus dihafal oleh umat Islam. Begitu juga dengan mengikut Imam Asy'ari dalam teologi, alGhazali dan al-Junaidi dalam Tasawuf. 30

Tetapi bagi Said Aqil, Ahlussunah harus direkonstruksi dengan maksud manhaj al-fikr (metode berpikir) setiap umat Islam, dengan berpegang teguh pada empat hal, yaitu tasammuh (toleransi), tawassuth (moderat), tawazzun (seimbang) dan ta'addul (adil). ${ }^{31}$ Keempat hal tersebut harus menjadi acuan umat Islam dalam berkehidupan, itulah ahlussunah wal jamaah. KH. Said bermaksud bahwa Aswaja tidak boleh sekadar keyakinan belaka, akan tetapi harus diaktualisasikan dengan hal yang lebih konkret dan bermanfaat bagi banyak orang.

29 Nizar Idris, Keteguhan Hati KH Said Aqil Siradj Ketika Badai Fitnah Menerpa, dalam www.muslimmoderat.net/2017/10/Keteguhan -Hati-KH-Said-Aqil-Siradj-Ketika-Badai-FitnahMenerpa.html?m=1, diakses pada 13 Maret 18, pkl. 13.21 WIB.

\section{Penutup}

Model dakwah yang dilakukan oleh Wali Songo adalah dakwah yang santun, tidak memaksa dan mengelaborasikan apa-apa yang telah diyakini masyarakat sebelum masuk Islam. Kegigihan Wali Songo dalam berdakwah dengan dibarengi kesabaran dan kecerdasan, membuat masyarakat mudah untuk menerima agama Islam. Aktualisasi tersebut diteruskan dan diaktualisasikan kembali (reaktualisasi) oleh KH. Said Aqil Siroj. Dalam setiap dakwahnya ia mengajak untuk bersatu, menjadi muslim yang santun, dan menjaga budaya serta tradisi yang sudah ada, dengan tanpa melanggar syariat. Ending-nya jargon Islam Nusantara, adalah produk dari proses dakwah yang ingin mewujudkan Islam santun, ramah, tidak mmemaksa dan bersinergi dengan tradisi-budaya.

30 AM. Waskito, Mendamaikan Ahlussunah wal Jamaah, (Jakarta: Pustaka alKautsar, 2012), h. 80.

${ }^{31}$ Said Aqil Siroj, Tasawuf sebagai Kritik Sosial: Mengedepankan Islam sebagai Inspirasi Bukan Aspirasi, (Bandung: Mizan Pustaka, 2006), h. 425. 


\section{DAFTAR PUSTAKA}

Bisri, Musthofa. Koridor: Renungan A. Musthofa Bisri, Jakarta: Kompas, 2010.

Burhanuddin, Jajat. Ulama dan Kekuasaan: Pergumulan Elite Politik Muslim dalam Sejarah Indonesia. Jakarta: Noura Book, 2012.

Chodim, Ahmad. Sunan Kalijaga, Jakarta: Serambi, 2013.

Efendi, Djohan. Merayakan Kebebasan Beragama: Bunga Rampai Merayakan 70 Tahun Djohan Efendi. Jakarta: ICPR \& Kompas, 2011.

Erdianto, Kristian. Ini Tanggapan PBNU Terkait Pidato Bupati Lampung yang Dinilai Lecehkan Said Aqil Siroj, lampung.tribun.com. 2018.

Febriando, Doni. Kembali Menjadi Manusia. Jakarta: Elexmedia Komputindo, 2014.

Hafidhuddin, Didin. Dakwah Aktual. Depok: Gema Insani, 1998.

Hamid, Abu Hamid. Syaikh Yusuf Makasar: Seorang Ulama, Sufi dan Pejuang. Jakarta: Yayasan Obor Indonesia, 1994.

Hatri, Anton. Said Aqil Tokoh Muslim Berpengaruh di Dunia. Media Indonesia, 2018.

Ibad, Muhammad Nurul. Perjalanan dan Ajaran Gus Meik. Yogyakarta: Lkis, 2017.

Ilyas, Mukhlisuddin. Aceh dan Romantisme Politik. Yogyakarta: Dianda Primamitra

Media, 2008.

Idris, Niza. Keteguhan Hati KH Said Aqil Siradj Ketika Badai Fitnah
Menerpa,

dalam

www.muslimmoderat.2018.

Kisswara, Adi Sucipto. Said Aqil Siroj: Islam Menjaga Keutuhan Negara, Nasionalisme Bagian dari Iman, http://kompas.id, diakses pada 13 Maret 2017.

Maryanto, Daniel Agus. Masjid Agung Demak. Jakarta: Grasindo, 2003.

Misrawi, Zuhairi. Madinah: Kota Suci, Piagam Madinah dan Teladan Muhammad Saw. Jakarta: Kompas, 2009.

Mulyati, Sri. Tasawuf Nusantara: Rangkaian Mutiara Sufi Terkemuka. Jakarta: Penerbit Kencana, 2017.

Naharong, Abdul Musi. Teologi Kekerasan: Pandangan Jihad Abdul Salam Faraj dan Imam Samudra, jurnal Teologi Paramadina, Vol. XVI, No. 1, Tahun. 2010.

Nur, Muhammad. Menyemai Kreator Peradaban. Jakarta: Penerbit Zaman, 2013.

Purwadi. Jejak Para Wali dan Ziarah Spiritual. Jakarta: Kompas, 2006.

Siroj, Said Aqil. Islam Kebangsaan: Fiqh Kebangsaan Kaum Santri. Jakarta: Fatma

Press, 1999.

Siroj, Said Aqil. Tasawuf sebagai Kritik Sosial: Mengedepankan Islam sebagai Inspirasi Bukan Aspirasi. Bandung: Mizan Pustaka, 2006.

Tjandrasasmita, Uka. Arkeologi Islam Nusantara. Jakarta: Gramedia, 2009.

Umam, Fawaizul. Kala Beragama Tak Lagi Merdeka. Jakarta: Gramedia, 2013. 
Waskito, AM. Mendamaikan Ahlussunah wal Jamaah. Jakarta: Pustaka alKautsar, 2012.

\section{Pidato:}

Ceramah Said Aqil Siroj dalam acara Newsmaker Metro TV, dengan judul "Pada Islam Nusantara Budaya Sebagai Infrastruktur Agama", didownload pada 13 Maret 2018.

Ceramah Said Aqil Siroj dalam acara Haul dan Tasyakkur Ponpes Khas Kempek, pada 13 Juni 2017 di Pondok Pesantren kempek Cirebon. 